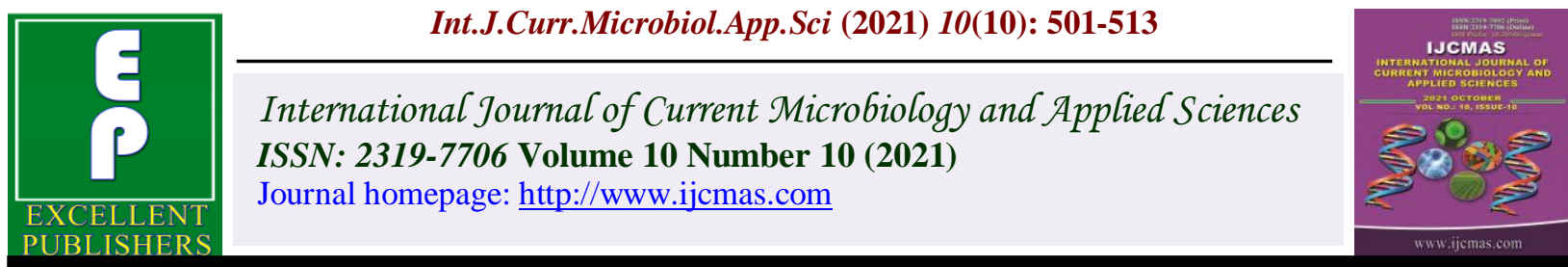

\title{
Impact Analysis of Kurichedu PMKSY Watershed Project on Land Use, Water Resources, Crop and Livestock Productivity in Prakasam District, Andhra Pradesh, India
}

\author{
P. V. R. M. Reddy ${ }^{1}$, M. Girija Shankar ${ }^{1}$, B. Janardhan Reddy ${ }^{1}$, Y. Shankar Naik ${ }^{1}$, \\ B. Swati ${ }^{2}$, P. Jayakannan ${ }^{2}$, V. S. Kiran ${ }^{2}$ and G. Prabhaker ${ }^{2}$
}

${ }^{1}$ PR and RD Department, Govt. of Andhra Pradesh, PVS ICON, D. No. 12 - 47, 3rd Floor, Pathuru Road, Tadepalli Village, Guntur, Andhra Pradesh-522 501, India

${ }^{2} N A B A R D$ Consultancy Services Pvt. Ltd (NABCONS), NABARD Building, 1-1-61, RTC 'X'

Road, Musheerabad, Hyderabad, Telangana State-500020, India

*Corresponding author

\section{A B S T R A C T}

\section{Keywords}

Natural Resource

Management,

Production System

Improvement,

Mahatma Gandhi

National Rural

Employment

Guarantee Scheme

Article Info

Accepted:

18 September 2021

Available Online:

10 October 2021
The study was piloted to assess the impact of watershed project interventions from 2011-2018, largely Natural Resource Management (NRM) and Production System Improvement (PSI) measures in Kurichedu PMKSY watershed project, Prakasam district, Andhra Pradesh. The specific objectives included detecting changes in agricultural land use, water body surface area, soil moisture; ground water levels, crop diversification, crop yields and livestock productivity. The net treatable area of the project is 4311 ha. Area under cultivated crops, both agriculture and horticulture crops increased by 414 ha, accounting to $16.6 \%$ over pre project period. The NRM activities augmented total water body surface area from 57 ha to 67 ha (17.5\%).Ground water table was mainly impacted by deficit rainfall. In kharif season, the area of rice and plantation crops are reduced, while the area of red gram, cotton and chilli improved. In rabi season, the area of tobacco decreased. The horticultural crop area in post project period increased by 84 ha. The productivity of both agricultural and horticultural crops increased during the project period. The yield increase ranged from 2.0 percent in red gram to 12.1 percent in cotton. The milk productivity enhanced from 2.3 to $3.2 \mathrm{~L}$ per animal per day with total milk production increase by 15.8 percent. The milk production increase per year in the project period is mainly due to higher milk yield per day per animal.

\section{Introduction}

Kurichedu in Kandukur division of Prakasam district, Andhra Pradesh is characterized with dry climate that has fluctuating amounts of rainfall, which often result in drought leading to scarce ground water resource, frequent insufficiency of food and fodder. The arable 
area is mostly rain fed with low productivity. Current rain fed farmer's crop yields in India are lower by 2- 5 folds than the achievable potential of rain fed agriculture and this potential needs to be tapped by adopting integrated watershed management approach on a large scale. The semi-arid tropics suffers from one or other kind of natural resource and other production base degradation (Grewel et al., 2001). Conservation of Natural resources would be the foremost challenge, particularly in arid and semi-arid tropics. In such a scenario, it is imperative to conserve natural resources and provide livelihood security through adopting integrated watershed management interventions. In reflection of these ground conditions, the PMKSY Watershed Development Component (erstwhile IWMP) is considered. Integrated watershed management has been a prominent approach for resource conservation and livelihood security in these areas (Samra 1997), to influence the productivity and production of crops, augment water resources, changes in land use and cropping pattern, adoption of modern technologies, increase in milk production, etc.

The purpose of the present study was to assess the impact of watershed project interventions such as NRM and PSI measures. The specific objectives included detecting changes during the project implementation period from 20112018 in terms agricultural land, water body surface area, soil moisture, ground water levels, crop diversification, crop yields and the livestock productivity, leading to sustainable agriculture and livelihoods for endurable overall development of stakeholders in the watershed area.

\section{Study Site}

The present study watershed project was implemented during 2011-18 in Kurichedu, located in DPAP block of Kurichedu Mandal,
Prakasam district (Fig.1). This PMKSY watershed is located between latitude $15^{\circ} 46^{\prime} 87^{\prime \prime}$ and longitude $79^{\circ} 35^{\prime} 44^{\prime \prime}$ at ridge point and between latitude $14^{\circ} 65^{\prime} 78^{\prime \prime}$ and longitude $79^{\circ} 33^{\prime} 21^{\prime \prime}$ at valley point. Highest point in the watershed is $30 \mathrm{~m}$ above the MSL. The net treatable area is 4311 hectares.

The average annual rainfall in the area is $771.2 \mathrm{~mm}$. The temperatures in the area are in the range of $42.17^{\circ} \mathrm{C}$ during summer and $25^{\circ} \mathrm{C}$ during winter. There are 2847 households in the project with a total population of 13,250 , inclusive of major social communities like SC-1830, ST-740, BC-5000, Minorities-430, others- 5250. The six Micro Watersheds (MWS) in the watershed project are Bayyaram, Kurichedu, Perambotla Palem, West Veerayapalem, Namahsivayapuram, and Mallayapalem.

\section{Material and Methods}

The change in land use and cover was assessed by integrating remote sensing and geographic information systems (GIS). The classified images having different land use land cover categories pertaining to pre and post treatment period were compared to derive information on changes. Remote sensing of vegetation liquid water from space was based on Normal Difference Water Index (NDWI); a satellite derived index from Near- Infrared (NIR) and Short-Wave for calculation of soil moisture. Survey of India Topo sheet in 1:50,000 scale has been consulted for the study of the watershed boundaries. Remote Sensing techniques of parametric models were used to measure the soil loss using the Universal Soil Loss empirical Equation (USLE).

The depth to ground water level in the project area was recorded in pre and post monsoon season during the project period. Piezometers were used as observation wells for recording 
groundwater levels. In the project area, two piezometers were installed, one each in the recharge zone (intermediary region) and storage zone (valley region). Month-wise rainfall data as recorded at mandal-level (administrative unit in Andhra Pradesh) was collected for the project period (2011-2018) and presented as annual rainfall received against the normal rainfall. Statistical tools like measures of central tendency (mean value) measures of dispersion (standard deviation) and coefficient of variation were computed.

A total of five percent of households in the project were interviewed during SeptemberOctober 2019 to collect information on crop yields, crop diversification as well as their livestock wealth by developing a survey tool to capture the relevant information. Another qualitative research tool is used to collect data through focus group discussion (FGD) from each micro watershed. The focus group comprises a small number of watershed community to discuss and assess their perceptions on the impact of watershed interventions on natural resource conservation and use, sustainability of crop and livestock production etc. This was further reinforced with the ancillary data sources, chiefly related to NRM and PSI activities from the Management Information System (MIS) of State Level Nodal Agency, Andhra Pradesh. Quantitative analysis (statistical and numerical) was later carried out to assess and quantify the impact of watershed interventions, wherever necessary.

\section{Results and Discussion}

\section{Impact on Land Use Land Cover}

In this study, before and after project satellite data was used to evaluate the following landscape changes during the project period from 2011-2018. The satellite imagery for land use land cover are given in Fig-2 and the data for agriculture crop land area and water body surface area are provided in Table 1 and 2.

\section{Change detection in agriculture land use}

Change in agriculture land use was assessed by integrating remote sensing and geographic information systems (GIS). These are now providing effective tools for advanced ecosystem and socio economic management (InzamulHaqueMdand RonyBasak, 2017). The Area under cultivated crops, both agriculture and horticulture crops increased by 414 ha, accounting to $16.6 \%$ over pre project period (Table-1).Watershed interventions showed significant modification and conversion of land use and cover of the watershed (FikirAlemayehu et al., 2009). Further, land use for agriculture and horticulture crops as assessed qualitatively by field visit through Focus Group Discussion (FGD) with beneficiaries and other sources of the project show that out of these 414 ha of crop area increase, 286 ha are agricultural crops and 128 ha horticultural crops. Agriculture crop area increased by $14.3 \%$ in kharif season, while the area in rabi season decreased from 217 to 189 ha (12.9\%). Greater impact was observed in cultivation of horticultural crops, particularly fruit crops with change in area from 75 to 203 ha $(170.7 \%)$ at the end of project period. The agriculture land area increased during the project period with change in area under vegetation (agro-plantations) and forest. Watershed interventions such as soil and moisture conservation measures, harvesting of rain water and recycling, development of waste lands and fallow lands resulted in land use change. Study of Amee K. Thakkar et al., (2017b) showed an increase in agricultural land and decrease in scrub forest over the period of ten years. The watershed management programs in semi-arid regions 
showed significant increase in agriculture crops (Nagaveni and Ravibabu, 2017).

\section{Change detection in surface water}

Land use land cover study detected positive change in water body surface during the project period (Table-2).

The thrust area of watershed program for rain water harvesting through natural resource management structures such as farm ponds, percolation tanks, check dams and repairs to existing structures has facilitated effective management of rainfall with improved water storage.

All the NRM activities listed in Table-3 augmented total water body surface area from 57 ha to 67 ha $(17.5 \%)$. The key land use land cover changes at watershed level in terms of the water body was reported by Amee K Thakkar et al., (2017a).

A number of water harvesting structures are taken up utilizing the funds from WS allocations and in convergence with MGNREGS of Govt of India flagship program; especially the farm ponds, inclusive of dugout ponds, and repairs to existing check dams (Table-3). Convergence of various rural development programmes around the watershed ensured holistic development of watershed areas (Palanisamia and Suresh Kumar, 2009). Implementation of Watershed program has resulted in increase of irrigated area at the end of project period. Overall there is an increase in the irrigated area in the project period to an extent of 4.8 percent in the watershed project.

The expansion in irrigated area due to watershed development activities has been found from 5.6 percent to 68.0 percent across regions and seasons (Palanisamia $\mathrm{K}$ and Suresh Kumar, 2009).

\section{Impact on Soil Moisture}

Changes in soil moisture was measured based on Normal Difference Water Index (NDWI). Watershed interventions influenced the soil moisture in project areas (Ranjit Basha et al., 2019). The area under low and medium soil moisture improved by 116 and 115 ha, respectively during the project period. However, the area under good soil moisture declined by 236 hectares (Table-4). The soil moisture conservation measures and plantations executed during project period (Table-5) especially in ridge and middle areas of the project under PMKSY and MGNREGA has benefited in moisture conservation in low and medium soil moisture areas, while similar impact was not observed in good soil moisture areas.

Category wise soil moisture conservation measures such as staggered trenches in hillock areas, digging peripheral trenches and greening of hillocks; and bund plantations are taken up on private and CPR lands(Table-5). Construction of marginal field bundings, gabions on primary streams, water spreaders in depressions and series of check dams on secondary and tertiary streams in treated watershed reduced the soil and nutrient losses in comparison to untreated watershed (Palsaniya et al., 2012).

\section{Impact on Ground Water}

Knowledge about the seasonal groundwater depth provide a vital element with regard to usage and management of groundwater. The ground water level varies with variability in the intensity, recharge, draft and runoff of rain water (JimmiDebbarma and Nibedita Das, 2019).The depth of water table as measured with piezometers show a drop in depth of water table from $6.02 \mathrm{~m}$ to $6.85 \mathrm{~m}$ bgl (Table$6)$, in spite of several Soil Moisture Conservation works (SMC) and Water 
Harvesting Structures (WHS). Ground water table was mainly impacted by deficit rainfall received in six years, out of eight years, of project implementation; increase in area under irrigation; drawing water from deeper depths; and increasing bore well number. Spatiotemporal change in pre and post-monsoon groundwater level reveals declining trend in groundwater, which may result into lowering of groundwater table, deterioration in the quality of water, and drying up of wells etc. (Jimmi Debbarma and Nibedita Das, 2019).

\section{Rainfall}

The actual rainfall received year wise against normal for the project period from 2011 to 2018 are provided in Table-7. In the year 2018, the rainfall received is only $273.8 \mathrm{~mm}$ against normal of $771.2 \mathrm{~mm}$. The mean rainfall across the project period is $560.8 \mathrm{~mm}$. The amount of variability or dispersion from the individual data values to the mean is worked out by computing the standard deviation. The computed Standard deviation value of 290.0 showed greater spread of a data distribution. The higher Co-efficient of Variation (CV) value clearly show greater level of dispersion around mean rainfall. Against normal rainfall of $771.2 \mathrm{~mm}$, the actual rainfall was below normal in six years ranging from 13.5 to $181.7 \%$ and above normal by $34.6 \%$ in just one year. A strong negative correlation observed between rainfall and groundwater level in pre-monsoon and post-monsoon seasons, which indicate that as rainfall increases the depth of groundwater decreases both in pre and post-monsoon periods (Jimmi Debbarma and Nibedita Das, 2019).

\section{Impact on Soil Erosion}

Survey of India Toposheet (Fig.3) in 1:50,000 scale has been consulted for the study of referencing and elevation information. The elevation difference between the minimum and maximum elevation contours of SOI topo sheet is $20 \mathrm{~m}$ only. The study shows no soil erosion in either of the satellite imageries of LISS IV data and with a spatial resolution of $5.8 \mathrm{~m}$. Thus, number of positive effects have resulted, like reduced sedimentation; reduced rainfall runoff; increased recharge of surface and sub-surfaces oil moisture; stabilization of gullies and banks of natural streams; and rehabilitation of degraded lands.

Wolka Kebede (2014) reported promising effects of SWC measures on reducing soil loss, trapping a significant quantity of sediment at early stages and improving soil moisture; crop yield improvement especially after two to five years of the structure in low rainfall areas.

\section{Impact on Crop Diversity}

The annual crops as rice, red gram, jowar, cotton, chilli; plantation crops like eucalyptus, subabul; fruit crops such as acid lime, papaya and guava are grown in kharif season with shift in extent of areas.

Distribution of crop area (\%) depicted in Fig. 4 show reduction in area under rice and plantation crops, while increase in pulses, cotton and chilli at the end of project period in kharif season. In rabi season, mostly tobacco, bengal gram and castor are grown in pre and post project periods, but the area under tobacco decreased.

The horticultural crop area in post project period increased by 84 ha. In addition to the acid lime, papaya and guava, the other fruit crops like papaya and apple ber are taken up during the project period. Crop area distribution in pre and post project period show that red gram occupy $32.8-34.4 \%$ of total cultivated area followed by cotton (18.6$20.1 \%)$, Chillies (11.5-12\%). 
Table.1 Change detection in agriculture land use

\begin{tabular}{|c|c|c|c|c|}
\hline \multirow[t]{2}{*}{ Land Use Class } & Pre project & Post project & \multicolumn{2}{|c|}{ Change } \\
\hline & Area, ha & Area, ha & Area, ha & Percent \\
\hline Agriculture crop land & 2489 & 2903 & 414 & 16.6 \\
\hline Agriculture & 2414 & 2700 & 286 & 11.8 \\
\hline kharif & 2197 & 2511 & 314 & 14.3 \\
\hline$r a b i$ & 217 & 189 & 28 & 12.9 \\
\hline Horticulture & 75 & 203 & 128 & 170.7 \\
\hline
\end{tabular}

(Source: NABCONS 2020a\&b)

Table.2 Change detection in water body surface area

\begin{tabular}{|c|c|c|c|c|}
\hline \multirow{2}{*}{ Land Use Class } & Pre project & Post project & \multicolumn{2}{|c|}{ Change } \\
\cline { 2 - 5 } & Area, ha & Area, ha & Area, ha & Percent \\
\hline Water body & 57 & 67 & 10 & 17.5 \\
\hline
\end{tabular}

(Source: NABCONS 2020b)

Table.3 Category wise water harvesting structures in watershed project

\begin{tabular}{|c|c|c|c|}
\hline \multirow{2}{*}{ Activity } & \multicolumn{3}{|c|}{ Number } \\
\cline { 2 - 4 } & PMKSY & MGNREGS & Total \\
\hline Farm Pond & - & 239 & 239 \\
\hline Mini Percolation Tank & 59 & - & 59 \\
\hline Dugout Pond & 128 & 262 & 390 \\
\hline Percolation Tank & 10 & - & 10 \\
\hline Check Dam & 22 & - & 22 \\
\hline Recharge Pit & - & 46 & 46 \\
\hline Repairs to Existing Check Dam & - & 6 & 6 \\
\hline
\end{tabular}

(Source: IWMP AP MIS. 2020a)

Table.4 Change detection in soil moisture

\begin{tabular}{|c|c|c|c|c|}
\hline \multirow{2}{*}{ Soil Moisture Type } & Pre Project & Post Project & \multicolumn{2}{|c|}{ Change } \\
\cline { 2 - 5 } & Area, ha & Area, ha & Area, ha & Percent \\
\hline Low Soil Moisture & 84 & 200 & 116 & 138 \\
\hline Medium Soil Moisture & 3155 & 3270 & 115 & 3.64 \\
\hline Good Soil Moisture & 3175 & 2939 & 236 & 7.43 \\
\hline
\end{tabular}

(Source: NABCONS 2020b) 
Table.5 Category wise soil moisture conservation measures and plantations

\begin{tabular}{|c|c|c|c|}
\hline Activity & \multicolumn{3}{|c|}{ Number } \\
\cline { 2 - 4 } & PMKSY & MGNREGS & Total \\
\hline Staggered Trenches (Hillock Areas) & 1 & 0 & 1 \\
\hline Digging of peripheral trench with machine & 1 & 0 & 1 \\
\hline Greening of Hillocks & 0 & 1 & 1 \\
\hline Block Plantation in Private Lands & 4 & 0 & 4 \\
\hline Bund Plantations & 27 & 47 & 74 \\
\hline
\end{tabular}

(Source: IWMP AP MIS. 2020a)

Table.6 Depth to ground water levels in the project area

\begin{tabular}{|c|c|c|}
\hline \multirow{2}{*}{ Year } & \multicolumn{2}{|c|}{ Depth to water level, bgl in metres } \\
\cline { 2 - 3 } & Pre monsoon season (May) & Post monsoon season (November) \\
\hline $\mathbf{2 0 1 1}$ & 4.86 & 5.59 \\
\hline $\mathbf{2 0 1 2}$ & 5.98 & 4.26 \\
\hline $\mathbf{2 0 1 3}$ & 6.77 & 1.00 \\
\hline $\mathbf{2 0 1 4}$ & 4.16 & 4.36 \\
\hline $\mathbf{2 0 1 5}$ & 5.27 & 5.56 \\
\hline $\mathbf{2 0 1 6}$ & 7.36 & 5.83 \\
\hline $\mathbf{2 0 1 7}$ & 6.06 & 4.59 \\
\hline $\mathbf{2 0 1 8}$ & 5.81 & 6.86 \\
\hline
\end{tabular}

(Source: GW\&WAD.2019)

Table.7 Annual Rainfall during the project period

\begin{tabular}{|c|c|c|c|c|}
\hline \multirow{2}{*}{ year } & \multicolumn{4}{|c|}{ Total Rainfall, mm (Jan-Dec) } \\
\cline { 2 - 5 } & Actual & Normal & \% of Normal & Above/Below \\
\hline $\mathbf{2 0 1 1}$ & 346.2 & 771.2 & $(-) 122.8$ & Below \\
\hline $\mathbf{2 0 1 2}$ & 798.0 & 771.2 & 3.4 & Normal \\
\hline $\mathbf{2 0 1 3}$ & 1179.2 & 771.2 & 34.6 & Above \\
\hline $\mathbf{2 0 1 4}$ & 293.1 & 771.2 & $(-) 163.1$ & Below \\
\hline $\mathbf{2 0 1 5}$ & 468.1 & 771.2 & $(-) 64.8$ & Below \\
\hline $\mathbf{2 0 1 6}$ & 448.7 & 771.2 & $(-) 71.9$ & Below \\
\hline $\mathbf{2 0 1 7}$ & 679.5 & 771.2 & $(-) 13.5$ & Below \\
\hline $\mathbf{2 0 1 8}$ & 273.8 & 771.2 & $(-) 181.7$ & Below \\
\hline Mean & \multicolumn{2}{|c|}{560.8} & & \\
\hline SD & \multicolumn{2}{|c|}{290.0} & & \\
\hline CV \% & 51.8 & & \\
\hline
\end{tabular}

(Source: IMD, 2020) 
Table.8 Type of PSI Activities in convergence with departments of agriculture and horticulture

(Source:IWMP AP MIS. 2020b)

\begin{tabular}{|c|c|}
\hline Activity type & Number \\
\hline Custom Hiring Center for Farm Machinery & 7 \\
\hline Farm Implements individual & 35 \\
\hline Individual High cost Machinery & 2 \\
\hline Sprinkler Irrigation System & 1 \\
\hline Water Carrying Pipes & 114 \\
\hline Tarpaulin Sheets & 15 \\
\hline Silpaulins (60x40 with 120 guage) & 2 \\
\hline Vegetable Mini Kits for Kitchen Garden & 150 \\
\hline
\end{tabular}

Table.9 Mean Crop Yields in Pre and Post project Period

\begin{tabular}{|c|c|c|c|c|}
\hline \multirow{2}{*}{ Crop } & Unit & \multicolumn{3}{|c|}{ Crop Yield } \\
\cline { 3 - 5 } & & Pre project & Post project & \% of Change \\
\hline Rice & q/ha & 53.9 & 55.6 & 3.2 \\
\hline Jowar & q/ha & 10.8 & 12 & 11.1 \\
\hline Red gram & q/ha & 9.8 & 10 & 2.0 \\
\hline Cotton & q/ha & 14.9 & 16.7 & 12.1 \\
\hline Chilli $($ dry $)$ & q/ha & 27.6 & 28.4 & 2.9 \\
\hline Tobacco & q/ha & 16.4 & 17 & 3.7 \\
\hline Bengal gram & q/ha & 12 & 13.1 & 9.2 \\
\hline Castor & q/ha & 8.2 & 9 & 9.8 \\
\hline Subabul & t/ha & 33.1 & 35 & 5.7 \\
\hline Eucalyptus & t/ha & 31.2 & 32.3 & 3.5 \\
\hline Papaya & t/ha & - & 44.7 & - \\
\hline Acid lime & t/ha & 22.1 & 23 & 4.1 \\
\hline Guava & t/ha & 18.1 & 19.6 & 8.3 \\
\hline Apple ber & t/ha & - & 12.4 & - \\
\hline
\end{tabular}

(Source: NABCONS 2020a) 
Table.10 PSI Activities for animal health coverage and infrastructure development

\begin{tabular}{|c|c|}
\hline Activity & Number \\
\hline Animal Health Coverage & 22 \\
\hline Animal Health Camps & 22 \\
\hline Fertility Camps & 372 \\
\hline Feed supply to pregnant animals (last 100 days) & 10 \\
\hline Infrastructure Development & \\
\hline Establishment of Travices & 38 \\
\hline Luffaloes for dairy & \\
\hline
\end{tabular}

(Source:IWMP AP MIS. 2020b)

Table.11 Milch cattle, milk production and productivity

\begin{tabular}{|c|c|c|c|c|}
\hline Indicator & Unit & Pre Project & Post Project & \% Change \\
\hline Milch Cattle & Number & 2550 & 2054 & $(-) 19.5$ \\
\hline Milk & L/day & 2.3 & 3.2 & 41.6 \\
\hline Milk Production & KL/Year & 5839 & 6759 & 15.8 \\
\hline
\end{tabular}

(Source: NABCONS 2020a)

Fig.1 Location map of PMKSY Watershed Project

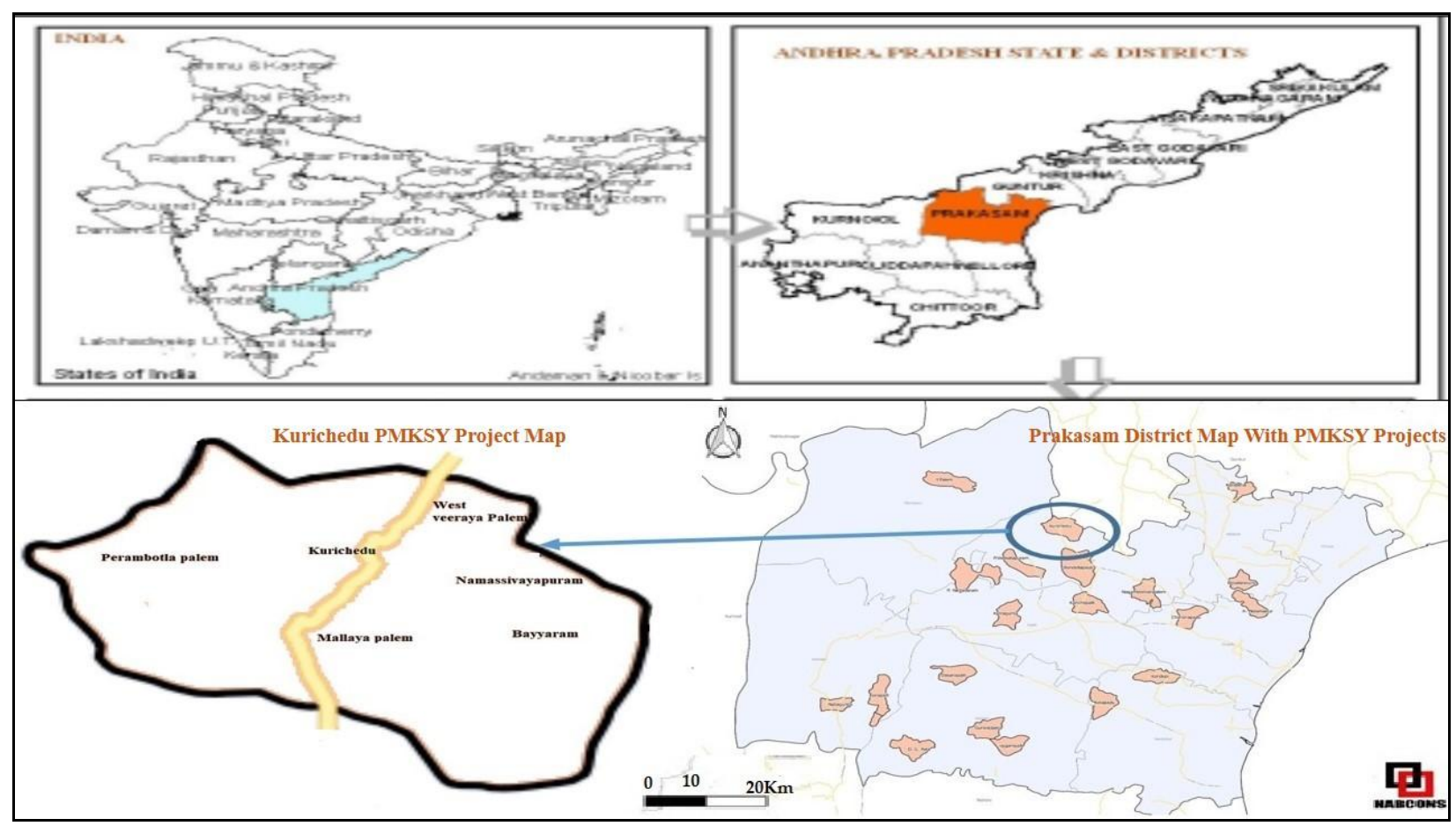


Fig.2 Land use Land cover (a) year 2011and (b) year 2018

A

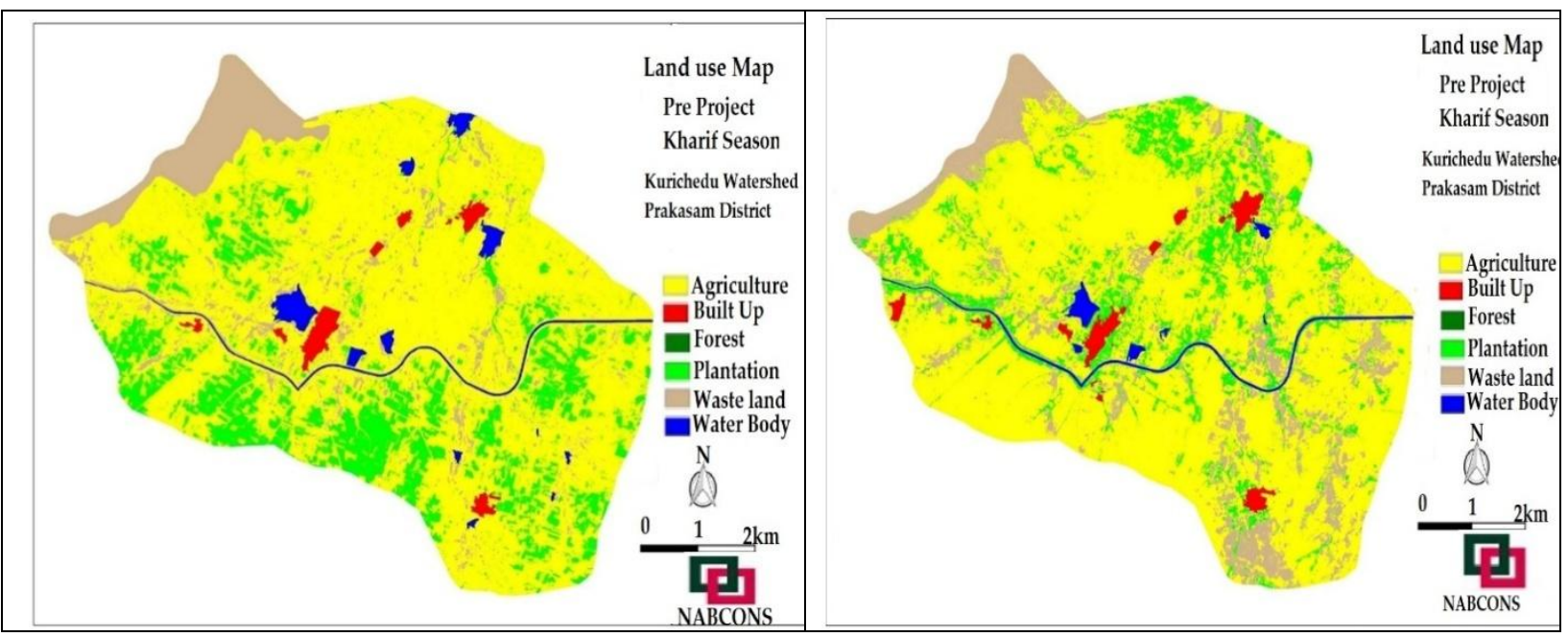

Fig.3 Toposheet of Watershed Project

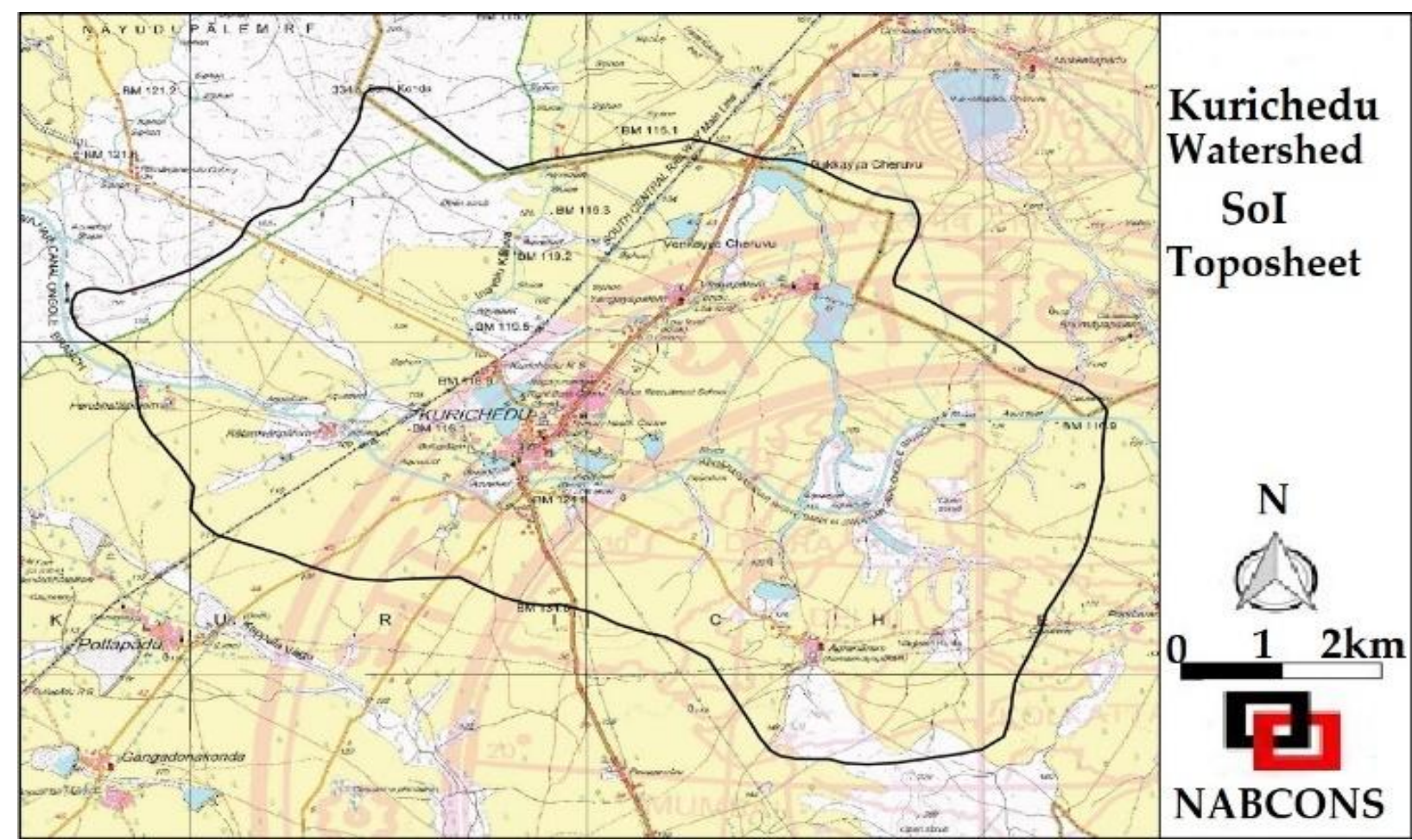


Fig.4 Cropping Pattern in Pre and Post Project period

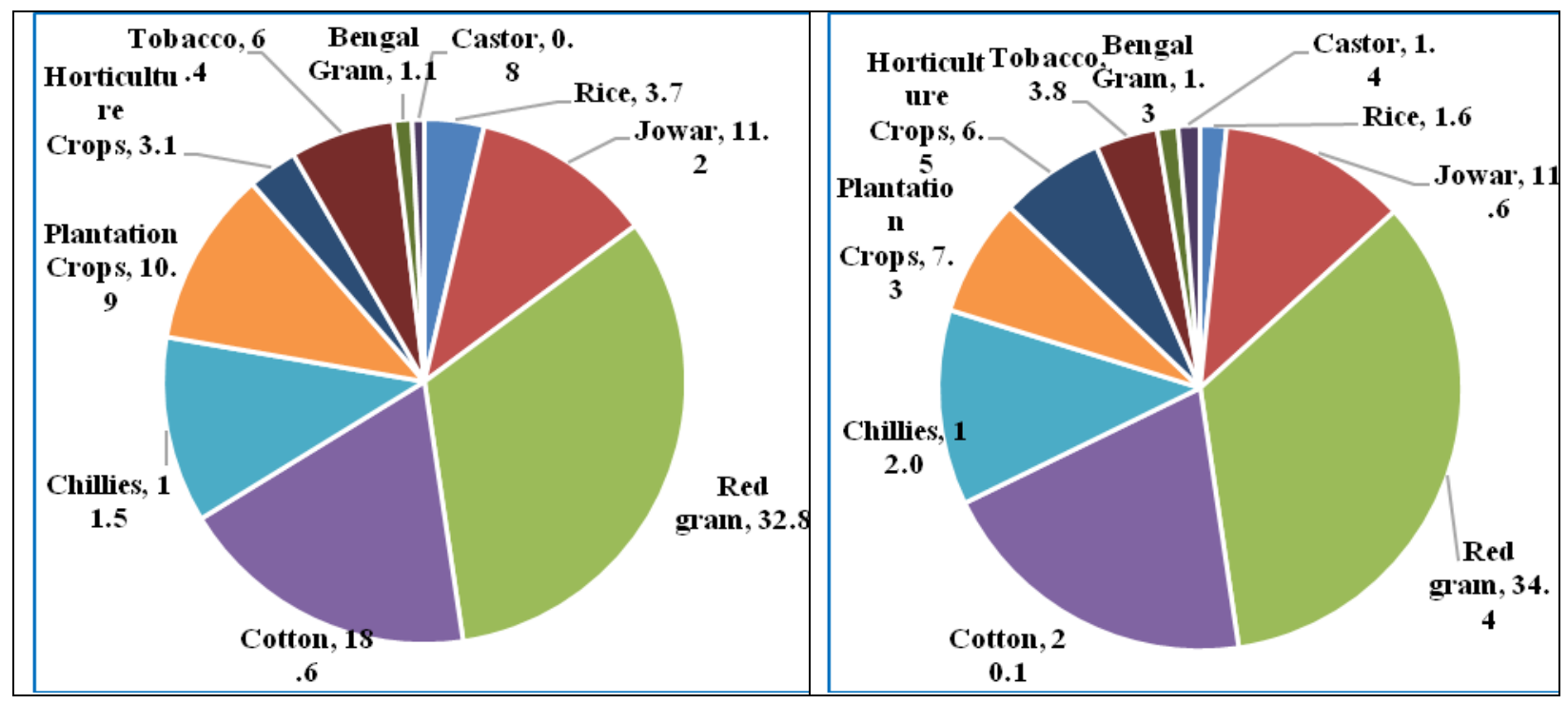

Availability of water resources changed the crops and cropping pattern in all the season in the watershed area (Garima Sharma and Sharma, 2020). The cropping pattern changes occur in areas under rain fed cultivation and well irrigation (Palanisamia and Suresh Kumar, 2009).

\section{Impact on Crop Productivity}

The per hectare economic yield of all major crops in the post project period was higher due to growing of high yielding crop varieties, adoption of recommended package of practices, effectively conserving and utilizing the soil moisture and rainfall. Convergence with agriculture and horticulture departments and associated production system improvement (PSI) activities (Table-8) have helped the farmers. Besides, the farmers were involved in capacity building (CB) programs of training, field demonstrations and exposure visits.The increased productivity in watershed is attributed to enhanced water availability for irrigation, spread of high yielding variety seeds (>70\% farmers use high-yielding seeds), optimum and balanced use of fertilizers, etc. (Palsaniya, 2012).
In respect of individual crops, the productivity of both agricultural and horticultural crops increased during the project period. The yield increase ranged from 2.0 percent in red gram to 12.1 percent in cotton (Table-9). The yield of crops are more due to adoption of improved cropping practices, conservation of soil moisture and judicious utilization of available irrigation, growing of high yielding varieties, timely credit supply etc. Yield increase was higher in jowar, cotton, castor and bengal gram. Among fruit crops, guava yielded higher $(8.3 \%)$, followed by acid lime (4.1\%).

\section{Impact on Milk Productivity}

Project interventions inclusive of PSI activities in convergence with Animal Husbandry department like animal health camps, fertility camps, establishment of travices, supply of improved breeds (Table10) to landless poor, marginal and small farmers, beside supply of fodder seed for green forage especially during lean (summer) months has impacted in achieving higher milk productivity in the project period. However, the milch cattle population during the project period decreased from 2550 to 2054 (19.5\%), 
in spite of supply of milch cattle to certain households. In a study by Reena et al., (2019) found that watershed development programs had weak impact on the population of livestock in watershed areas of Hisar and Kaithal districts of Haryana State. The decrease in cattle number is due to lack of interest among households, non-availability of labour for cattle rearing, increase in wages, shortage of open grazing lands, shortage of fodder supply, unremunerated price etc. and recurring drought conditions. Even though cattle population decreased, the total milk production increased by 15.8 percent from 5839 to $6759 \mathrm{KL} / \mathrm{Yr}$ (Table-11). The milk production increase per year in the project period is mainly due to higher milk yield per day per animal due to supply of improved breeds, artificial insemination, improved hygiene, improvement in lactation period, health management and balanced nutrition. The households who own milch cattle have additional or supplementary income to meet the family expenditure, even during drought years.

Implementation of key components of watershed interventions, mainly Natural Resource Management(NRM) and Production System Improvement(PSI) along with other activities, in convergence with the schemes or programs like MGNREGA and participation of related line departments of Government such as agriculture, horticulture, animal husbandry and rural development has impacted in sustainable agriculture area, crop productivity and milk yield, in spite of six deficit rainfall years and reduced ground water resources. This study confirms the importance of $P M K S Y$ watershed interventions as vital for poverty alleviation and sustainable livelihood.

\section{Acknowledgements}

The impact evaluation study of Kurichedu $P M K S Y$ watershed project is funded and supported by the Panchayat Raj and Rural
Development Department, Government of Andhra Pradesh. NABARD Consultancy Services (P) Limited (NABCONS), a wholly owned subsidiary of NABARD and MEL\&D agency for $P M K S Y$ watershed projects in cluster-III (Prakasam and Guntur) of Andhra Pradesh has conducted the study. The authors sincerely thank the Commissioner, PR\&RD and CEO, SLNA, the Director (WS) and Joint Commissioner (WS), Government of A. P, Vijayawada for the permission accorded to access the reports available at SLNA web site (iwmp.ap.gov.in).

\section{References}

Amee K. Thakkar, Desai V. R, Ajay Patel, Madhukar PotdarB.2017a. Impact assessment of watershed management programmes on land use/land cover dynamics using remote sensing and GIS. Remote Sensing Applications: Society and Environment, Vol.5:1-15

Amee K. Thakkar, Desai V. R, Ajay Patel, MadhukarPotdarB.2017b. Post-classification corrections in improving the classification of Land Use/Land Cover of arid region using RS and GIS: The case of Arjuni watershed, Gujarat, India. Space Science, Vol. 20(1):79-89

Fikir Alemayehu, Nurhussen Taha, Jan Nyssen, Atkilt Girma, Amanuel Zenebe, Mintesinot Behailu, Seppe Deckers, Jean Poesen.2009.The impacts of watershed management on land use and land cover dynamics in Eastern Tigray(Ethiopia). Resouces, Conservation and Recycling, Vol.53 (4):192-198

Garima Sharma, Sharma Dr. R N 2020. Application of GIS and Remote Sensing for the Impact Assessment of Integrated Watershed Management Program: A Case Study of Bassi Block, Jaipur District. International Journal of Scientific \& Technology Research, Vol.9(1):983-89

Ground Water and Water Audit department (GW\&WAD). 2019. Mandal wise Ground water level data of Prakasam District. Directorate of Ground Water and Water 
Audit Department, Ongole, Andhra Pradesh. Indian Meteorological Department (IMD). 2020. Customized Rainfall Information System (CRIS), Hydromet Division, Ministry of Earth Sciences, New Delhi. http://hydro.imd.gov.in/hydrometweb/(S(ab wy3n45bw3mbj55rryeh2e5))/DistrictRaifall. aspx

Inzamul Haque Md and Rony Basak. 2017. Land cover change detection using GIS and remote sensing techniques: A spatiotemporal study on Tanguar Haor, Sunamganj, Bangladesh. The Egyptian Journal of Remote Sensing and Space Science, Vol. 20(2):251-263

IWMP AP MIS. R.2.1 (A). 2020a. NRM category wise report, Management Information System, Integrated Watershed Management Programme, Andhra Pradesh. http://103.129.73.28/Webreports/UI/Works/ NRM_category_new.aspx

IWMP AP MIS. R.10.2. 2020b. PSI report, Management Information System, Integrated Watershed Management Programme, Andhra Pradesh. http://103.129.73.28/Webreports/UI/PSI/PSI _Activity.aspx

Jimmi Debbarma and Nibedita Das (Pan). 2019. A Spatio-temporal study on fluctuation in premonsoon and post-monsoon groundwater level in Tripura, North-east India. International Journal of Advanced Scientific Research and Management, Vol.4 (2):39-48

NABCONS. 2020a. Impact Evaluation Report of PMKSY Watersheds of Batch-III (2011-12) Projects in Prakasam District, Andhra Pradesh. NABARD Consultancy Services, Hyderabad, Telangana. (Unpublished).

NABCONS. 2020b. Remote Sensing and GIS Technology Based Impact Assessment of Batch III (2011-12) Projects of
WDCPMKSY Watershed Projects in Prakasam District. NABARD Consultancy Services, Hyderabad, Telangana. (Unpublished).

Nagaveni Chokkavarapu and Venkata Ravibabu Mandla. 2017. Impact Assessment of Watershed Management on Land Use/Land Cover Change Using RS and GIS: A Case Study. International Journal of Civil Engineering and Technology (IJCIET), Vol. 8(4):394-400

Palanisamia, K and Suresh Kumar D. 2009. Impacts of Watershed Development Programmes: Experiences and Evidences from Tamil Nadu. Agricultural Economics Research Review, Vol. 22 (Conference Number):387-396

Palsaniya D R, Ramesh Singh, Tewari R K, Yadav R S and Dhyani S K.2012.Integrated watershed management for natural resource conservation and livelihood security in semiarid tropics of India. Indian Journal of Agricultural Sciences, Vol.82(3): 241-7

Ranjit Basha P, Siva Prasad M, Venkatesulu Naik B, Inigo Arul Selvan R, Sudhakar Reddy L. 2019. Study on Impact Assessment of Mega Watershed Project in Prakasam District, Andhra Pradesh, India. International Journal of Science and Research (IJSR), Vol.8(7):236-42

Reena , Manoj Siwach, Abhey Singh. 2019. Impact of Watershed Development Programmes on Livelihood Conditions of Farmers in Haryana. Journal of Rural Development, Vol.38 (1):144-70

Wolka Kobede. 2014. Effect of Soil and Water Conservation Measures and Challenges for its Adoption: Ethiopia in Focus. Journal of Environmental Science and Technology, Vol. 7(4):185-199

\section{How to cite this article:}

Reddy, P. V. R. M., M. Girija Shankar, B. Janardhan Reddy, Y. Shankar Naik, B. Swati, P. Jayakannan, V. S. Kiran and Prabhaker, G. 2021. Impact Analysis of Kurichedu PMKSY Watershed Project on Land Use, Water Resources, Crop and Livestock Productivity in Prakasam District, Andhra Pradesh, India. Int.J.Curr.Microbiol.App.Sci. 10(10): 501-513. doi: https://doi.org/10.20546/ijcmas.2021.1010.060 